\title{
Genetic Diversity Analysis of Ash Gourd [Benincasa hispida (Thunb.) Cogn.] Germplasm by Principal Components
}

\author{
Kalyani Pradhan ${ }^{*}$, Alok Nandi², Swarnalata Das², Subrata Sarkar², \\ Gouri Shankar Sahu ${ }^{1}$ and Anjana Patnaik ${ }^{2}$ \\ ${ }^{1}$ Department of Vegetable Science, College of Agriculture, Orissa University of Agriculture \\ and Technology, Bhubaneswar-751003, Odisha, India \\ ${ }^{2}$ All India Coordinated Research Project on Vegetable Crops, Orissa University of \\ Agriculture and Technology, Bhubaneswar-751003, Odisha, India \\ *Corresponding author
}

\section{A B S T R A C T}

Ash gourd is an under-exploited but important vegetable crop in which genetic diversity has been studied to a very limited extent. Field experiments were, therefore, conducted during the rainy seasons of 2015 and 2016, in order to study the genetic diversity in 18 ash gourd genotypes (11 landraces +7 released varieties). The genotypes were grouped into

\section{Keywords}

Genetic divergence, Ash gourd, $\mathrm{D}^{2}$ analysis, Clustering, Principal component analysis

Article Info

Accepted:

20 February 2018

Available Online:

10 March 2018 three clusters. Clusters I, II and III contained six, three and nine genotypes respectively. Cluster III consisted of all the released varieties except Pusa Ujwal. The inter cluster distance between clusters I and II was the highest followed by the distance between clusters I and III. There was existence of wide genetic divergence among the landraces collected from very small to small geographical areas in villages of Odisha state. Cluster I had the maximum mean values for branches/plant and number of fruits/plant. Cluster III had the highest mean values for number of female flowers/plant, sex ratio, average fruit weight, fruit girth, vine length and fruit yield/plant. Relative contribution of fruit yield per plant to genetic divergence of genotypes in ash gourd was the maximum. The Principal Component Analysis (PCA) in general confirmed the groupings obtained through clustering (Tocher's) with some deviations. PCA revealed four informative components accounting for $71.51 \%$ variance. PC1 was related with fruit weight, fruit diameter, yield/plant, fruit length, weight of seeds/ fruit, branches/plant and vine length. The genotype BAGS-1(cluster I) may be crossed with BAGS-7(cluster II) or with the genotypes BAGS-10, Kashi Ujwal or Pusa Urmi (cluster III) for achieving higher heterosis.

\section{Introduction}

A large number of cucurbitaceous species, which have not been exploited or are underexploited, have a great potential for contributing to nutritive food requirement. Among them, ash gourd (Benincasa hispida) is important (Pandey et al., 2015). Ash gourd is also known by a variety of names such as winter gourd, winter melon, white gourd, Chinese preserving melon, pith gourd, wax gourd, Chinese wax gourd, tallow gourd and Chinese water melon (Tindall, 1986; Pandey et al., 2015). 
Indo-China region is the centre of diversity for ash gourd (Rubatzky and Yamaguchi, 1997; Pandey et al., 2015). Indo-China region being a centre of diversity is endowed with great variability in terms of morphological characters especially, growth habit and maturity including shape, size and flesh thickness of fruits (Rubatzky and Yamaguchi, 1997). Rind and seeds of a gourd discovered at the Kana site in Papua New Guinea are identified as remains of Benincasa hispida. Therefore, it may be possibly domesticated at the Kana site (Matthew, 2003).

Ash gourd is an important vegetable mainly valued for its long storage life and good scope for value addition. The fruits are consumed as baked, fried, boiled, pickled or candied/preserved (Robinson and DeckerWalters, 1999). World famous confectionery known as Petha is prepared using ripe flesh in sugar syrup. Ash gourd is valued for its medicinal attributes especially in Ayurveda for the cure of peptic ulcer and the fruit juice is used for treating a range of ailments including insanity and epilepsy. It can also prevent kidney damage (Pandey, 2008). Its fruits contain a relatively high level of $\mathrm{K}$ and low $\mathrm{Na}$ and from the index of nutritional quality value, it has been adjudged as a quality vegetable (Pandey, 2008).

In India, although a wide range of variability is available for different component characters in ash gourd (Mandal et al., 2002), but very sporadic efforts have been made so far for its genetic improvement. The fact that almost no hybrid is under cultivation also reflects the negligence of crop improvement in ash gourd. A wide range of genetic diversity among parents is an essential requirement of any successful hybridization programme. Hence, plant breeders must make sincere efforts to estimate the extent of genetic diversity among different genotypes (varieties and landraces), which will help them to achieve the set goal through appropriate breeding strategies. Mahalanobis $\mathrm{D}^{2}$ analysis provides a means for assessment of genetic diversity among crop plants (Mahalanobis, 1936). Since research work on genetic diversity of ash gourd is very meager, the present experiment was undertaken to collect local landraces of ash gourd and assess their genetic diversity in relation to the available released varieties of the crop, with the objective of their potential use in further crop improvement.

\section{Materials and Methods}

Eighteen genotypes of ash gourd comprised of 11 promising landraces collected from different villages of Odisha state in India and 7 released varieties were taken for the study (Table 1). The experiment was conducted in the Randomized Block Design with three replications at the All India Coordinated Research Project on Vegetable Crops, Orissa University of Agriculture and Technology, Bhubaneswar, Odisha, India, during the rainy seasons of 2015 and 2016. Seeds were sown in plots measuring $3 \mathrm{~m} \times 3 \mathrm{~m}$, accommodating 9 hills/plot and 3 plants /hill. The hills were spaced $1.0 \mathrm{~m}$ either way. Observations were recorded on 13 quantitative traits namely branches/plant, vine length, node to 1 st female flower, number of female flowers /plant, sex ratio(female: male flowers), days to 1st fruit setting, fruits/plant, fruit length, fruit girth, fruit weight, seeds /fruit, weight of seeds/fruit, fruit yield/ plant. Data of quantitative traits were recorded on five randomly selected competitive plants per accession and subjected to Analysis of Variance (Panse and Sukhatme, 1978). The data were subjected to multivariate analysis (Rao, 1952). The original mean values were transformed to normalized variables and all $\mathrm{D}^{2}$ values were calculated. The grouping of genotypes was done by using Tocher's 
method as described by Rao (1952). The criterion used in clustering by this method is that genotypes belonging to the same cluster should show a smaller $\mathrm{D}^{2}$ value than those belonging to different clusters.

Classification (cluster) and ordination (principal components) analyses were also performed. Skewed data on quantitative traits were transformed before multivariate analysis. Principal components analysis was performed using quantitative traits. The statistical analysis was carried out using INDOSTAT statistical package developed at the INDOSTAT Services, Hyderabad, India.

\section{Results and Discussion}

The aim of this study was to assess the genetic diversity amongst ash gourd genotypes. Table 1 depicts the list of genotypes included in the study. The landraces were collected from different villages of Odisha state in India as per the respective coordinates of places shown therein. The released varieties were procured from Indian Institute of Vegetable Research and Indian Agricultural Research Institute. A perusal of Table 2 shows that on the basis of pooled data of 2 years, the 18 genotypes of ash gourd could be grouped into 3 clusters depending on their genetic divergence. Cluster III comprised of highest number of genotypes (9). Cluster I and II had 6 and 3 genotypes respectively. The distance between clusters I and II was the highest and this was followed by the distance between clusters I and III (Table 3). Heterosis is of direct relevance for developing hybrids in both cross and self-pollinated crops. It is increasingly realized that crosses between divergent parents usually produce greater heterotic effect than those between closely related ones (Kumar et al., 2006; Dey et al., 2007). The more diverse are the parents within their limits of fitness, greater are the chances of achieving more heterotic effects and a broad spectrum of variability in segregating generations (Lovely et al., 2004). Sureja et al., (2006) and Verma et al., (2007) reported significant positive correlations of genetic distance with hybrid performance and heterosis.

The landraces BAGS 2 and BAGS 9 collected from the same village of Gambhari in Bolangir district, were placed in divergent clusters I and III respectively. Again, the landraces BAGS 4 and BAGS 8 which originated from the same village of Kuligaon in Nuapada district were also placed in divergent clusters. The genotypes BAGS 1 and BAGS 9 belonging to the same geographical area (Bolangir district) were grouped in the two divergent clusters I and III respectively. This reveals the existence of wide genetic divergence within a very small to small geographical area. It may be due to the fact that Indo-China region is the centre of diversity (Rubatzky and Yamaguchi, 1997; Pandey et al., 2015). The variety Pusa Ujwal, which originated from the same location (New Delhi) as the varieties Pusa Urmi, Pusa Sabji Petha and Pusa Shreyali, was placed in a different cluster genetically. Therefore, it is observed that genetic divergence was not strictly in agreement with geographical divergence which corroborates the findings of Lovely and Devi (2004) and Singhal et al., (2010).

The fact that cluster I contains all the landraces and no released varieties at all, also opens up newer possibilities of selecting promising genotypes with higher number of fruits/plant, which have genetic distinctness and almost no genetic similarity with the released varieties presently available in India. Owing to their better adaptability to the agroclimatic conditions of Odisha, varieties thus developed from the landraces, are expected to perform better in Odisha than the released varieties. 
Table.1 List of genotypes (local landraces and varieties) taken for the study

\begin{tabular}{|l|l|l|l|l|}
\hline \multirow{2}{*}{ Sl.no. } & Land races & \multicolumn{1}{|c|}{ Source } & \multirow{2}{*}{ Coordinates of the places } \\
\cline { 2 - 4 } & & \multicolumn{1}{|c|}{ Village/Town } & \multicolumn{1}{|c|}{ District and State } & \\
\hline $\mathbf{1}$ & BAGS-1 & Bhaludunguri & Bolangir, Odisha & $20.9161^{\circ} \mathrm{N}, 83.1086^{\circ} \mathrm{E}$ \\
\hline $\mathbf{2}$ & BAGS-2 & Gambhari & Bolangir, Odisha & $19.7215^{\circ} \mathrm{N}, 85.4698^{\circ} \mathrm{E}$ \\
\hline $\mathbf{3}$ & BAGS-3 & Kuligaon & Nuapada, Odisha & $22.2770^{\circ} \mathrm{N}, 84.2516^{\circ} \mathrm{E}$ \\
\hline $\mathbf{4}$ & BAGS-4 & Banjibahal & Nuapada, Odisha & $20.3890^{\circ} \mathrm{N}, 82.6834^{\circ} \mathrm{E}$ \\
\hline $\mathbf{5}$ & BAGS-5 & Biswanathpur & Nuapada, Odisha & $19.8056^{\circ} \mathrm{N}, 83.0632^{\circ} \mathrm{E}$ \\
\hline $\mathbf{6}$ & BAGS-6 & Badasasan & Angul, Odisha & $19.1607^{\circ} \mathrm{N}, 84.7727^{\circ} \mathrm{E}$ \\
\hline $\mathbf{7}$ & BAGS-7 & Jholpathar & Nuapada, Odisha & $20.8444^{\circ} \mathrm{N}, 85.1511^{\circ} \mathrm{E}$ \\
\hline $\mathbf{8}$ & BAGS-8 & Gambhari & Bolangir, Odisha & $20.3971^{\circ} \mathrm{N}, 82.7374^{\circ} \mathrm{E}$ \\
\hline $\mathbf{9}$ & BAGS-9 & Kuligaon & Nuapada, Odisha & $19.7215^{\circ} \mathrm{N}, 85.4698^{\circ} \mathrm{E}$ \\
\hline $\mathbf{1 0}$ & BAGS-10 & Dashapalla & Nayagarh, Odisha & $20.3890^{\circ} \mathrm{N}, 82.6834^{\circ} \mathrm{E}$ \\
\hline $\mathbf{1 1}$ & BAGS-11 & & & $20.3356^{\circ} \mathrm{N}, 84.8490^{\circ} \mathrm{E}$ \\
\hline & Released varieties & IIVR, Varanasi & Varanasi, Uttar Pradesh & $25.3176^{\circ} \mathrm{N}, 82.9739^{\circ} \mathrm{E}$ \\
\hline $\mathbf{1 2}$ & Kashi Dhawal & IIVR, Varanasi & Varanasi, Uttar Pradesh & $25.3176^{\circ} \mathrm{N}, 82.9739^{\circ} \mathrm{E}$ \\
\hline $\mathbf{1 3}$ & Kashi Ujwal & IIVR, Varanasi & Varanasi, Uttar Pradesh & $25.3176^{\circ} \mathrm{N}, 82.9739^{\circ} \mathrm{E}$ \\
\hline $\mathbf{1 4}$ & Kashi Surbhi & IARI, Varanasi & Delhi, Uttar Pradesh & $28.6139^{\circ} \mathrm{N}, 77.2090^{\circ} \mathrm{E}$ \\
\hline $\mathbf{1 5}$ & Pusa Ujwal & IARI, New Delhi & Delhi, Uttar Pradesh & $28.6139^{\circ} \mathrm{N}, 77.2090^{\circ} \mathrm{E}$ \\
\hline $\mathbf{1 6}$ & Pusa Urmi & IARI, New Delhi & Delhi, Uttar Pradesh & $28.6139^{\circ} \mathrm{N}, 77.2090^{\circ} \mathrm{E}$ \\
\hline $\mathbf{1 7}$ & Pusa Sabji Petha & IARI, New Delhi & Delhi, Uttar Pradesh & $28.6139^{\circ} \mathrm{N}, 77.2090^{\circ} \mathrm{E}$ \\
\hline $\mathbf{1 8}$ & Pusa Shreyali & & \\
\hline
\end{tabular}

Table. 2 Clustering pattern of 18 genotypes in ash gourd (Tocher's method)

\begin{tabular}{|l|l|l|}
\hline Cluster & No. & \multicolumn{2}{|c|}{ Genotypes } \\
\hline I & 6 & BAGS-1, BAGS-2, BAGS-3, BAGS-4, BAGS-5, BAGS-6 \\
\hline II & 3 & BAGS-7, PUSA UJWAL, BAGS-11 \\
\hline III & 9 & $\begin{array}{l}\text { BAGS-8, BAGS-9, BAGS-10, Kashi Dhawal, Kashi Ujwal, Kashi } \\
\text { Surbhi, Pusa Urmi, Pusa Sabji Petha, Pusa Shreyali }\end{array}$ \\
\hline
\end{tabular}

Table.3 Intra (diagonal) and inter cluster average $D^{2}$ and corresponding $D\left(\sqrt{ } D^{2}\right)$ values (in parenthesis) among groups

\begin{tabular}{|l|c|c|c|}
\hline Clusters & I & II & III \\
\hline I & 339.416 & 600.212 & 448.281 \\
& $(18.423)$ & $(24.499)$ & $(21.173)$ \\
\hline II & & 270.792 & 374.199 \\
& & $(16.456)$ & $(19.344)$ \\
\hline III & & & 365.249 \\
& & & $(19.111)$ \\
\hline
\end{tabular}


Table. 4 Cluster wise mean values of 13 characters of genotypes in ash gourd

\begin{tabular}{|l|l|l|l|l|l|l|l|l|l|l|l|l|l|}
\hline $\begin{array}{l}\text { Cluster/ } \\
\text { Characte } \\
\text { r }\end{array}$ & $\begin{array}{l}\text { No. of } \\
\text { branches } \\
\text { /plant }\end{array}$ & $\begin{array}{l}\text { Node } \\
\text { to 1st } \\
\text { female } \\
\text { flower }\end{array}$ & $\begin{array}{l}\text { No. of } \\
\text { female } \\
\text { flowers } \\
\text { /plant }\end{array}$ & $\begin{array}{l}\text { Sex ratio } \\
\text { (Female: } \\
\text { Male }\end{array}$ & $\begin{array}{l}\text { Days } \\
\text { flowers }\end{array}$ & $\begin{array}{l}\text { No. of } \\
\text { fruit } \\
\text { fetting } \\
\text { fruits/ } \\
\text { plant }\end{array}$ & $\begin{array}{l}\text { Fruit } \\
\text { length }\end{array}$ & $\begin{array}{l}\text { Fruit } \\
\text { girth }\end{array}$ & $\begin{array}{l}\text { Fruit } \\
\text { weight }\end{array}$ & $\begin{array}{l}\text { Seeds } \\
\text { /fruit }\end{array}$ & $\begin{array}{l}\text { Weight of } \\
\text { seeds/fruit }\end{array}$ & $\begin{array}{l}\text { Vine } \\
\text { length }\end{array}$ & $\begin{array}{l}\text { Yield/ } \\
\text { plant }\end{array}$ \\
\hline I & 2.373 & 26.167 & 30.917 & 0.092 & 58.833 & 4.538 & 18.672 & 15.027 & 1811.451 & 401.137 & 20.252 & 528.169 & 3489.957 \\
\hline II & 2.203 & 26.417 & 29.583 & 0.105 & 62.000 & 4.257 & 21.313 & 15.338 & 2343.488 & 565.368 & 31.675 & 534.440 & 4830.340 \\
\hline III & 2.272 & 25.778 & 32.278 & 0.117 & 57.694 & 3.823 & 21.296 & 16.332 & 2590.732 & 460.285 & 27.552 & 645.847 & 6174.301 \\
\hline
\end{tabular}

Table.5 Relative contribution of different characters to genetic divergence of genotypes in ash gourd

\begin{tabular}{|l|c|c|}
\hline \multicolumn{1}{|c|}{ Character } & No. of first rank & \% Contribution \\
\hline Branches/plant & 0 & 0.0000 \\
\hline Node to 1st female flower & 0 & 0.0000 \\
\hline Female flowers /plant & 1 & 0.6536 \\
\hline Sex ratio & 0 & 0.0000 \\
\hline Days to 1 fruit setting & 0 & 0.0000 \\
\hline Fruits/plant & 1 & 0.6536 \\
\hline Fruit length & 1 & 0.6536 \\
\hline Fruit diameter & 9 & 5.8824 \\
\hline Fruit weight & 0 & 0.0000 \\
\hline Seeds/fruit & 9 & 5.8824 \\
\hline Weight of seeds/ fruit & 3 & 1.9608 \\
\hline Vine length & 60 & 39.2157 \\
\hline Yield/plant & 69 & 45.0980 \\
\hline Total & 153 & 100 \\
\hline
\end{tabular}


Table.6 Eigen values, cumulative variance of the first four principal components (PCs) and factor loading between PCs and descriptors studied

\begin{tabular}{|l|l|l|l|l|}
\hline & PC1 & PC2 & PC3 & PC4 \\
\hline Eigen value & 4.37 & 2.61 & 1.22 & 1.09 \\
\hline Percent of variance & 33.64 & 20.11 & 9.38 & 8.39 \\
\hline Cumulative variance & \multicolumn{1}{|c|}{ Descriptors } & \multicolumn{4}{|c|}{ Factor loadings } \\
\hline \multicolumn{1}{|c|}{ Branches/plant } & .315 & -.497 & .565 \\
\hline Node to 1st female flower & -.591 & .203 & .088 & -.064 \\
\hline Female flowers /plant & -.649 & .538 & .153 & .171 \\
\hline Sex ratio & .096 & .206 & .178 & .795 \\
\hline Days to 1 st fruit setting & -.458 & .635 & .198 & .082 \\
\hline Fruits/plant & -.254 & .287 & .232 & .355 \\
\hline Fruit length & .702 & .501 & -.254 & .023 \\
\hline Fruit diameter & .855 & .230 & -.229 & .015 \\
\hline Fruit weight & .888 & .106 & -.010 & .208 \\
\hline Seeds/fruit & .270 & .775 & .228 & -.316 \\
\hline Weight of seeds/ fruit & .566 & .667 & .299 & -.253 \\
\hline Vine length & .298 & -.335 & .695 & -.112 \\
\hline Yield/plant & .850 & -.189 & .061 & .268 \\
\hline
\end{tabular}

Figure.12D principal components scatter plot

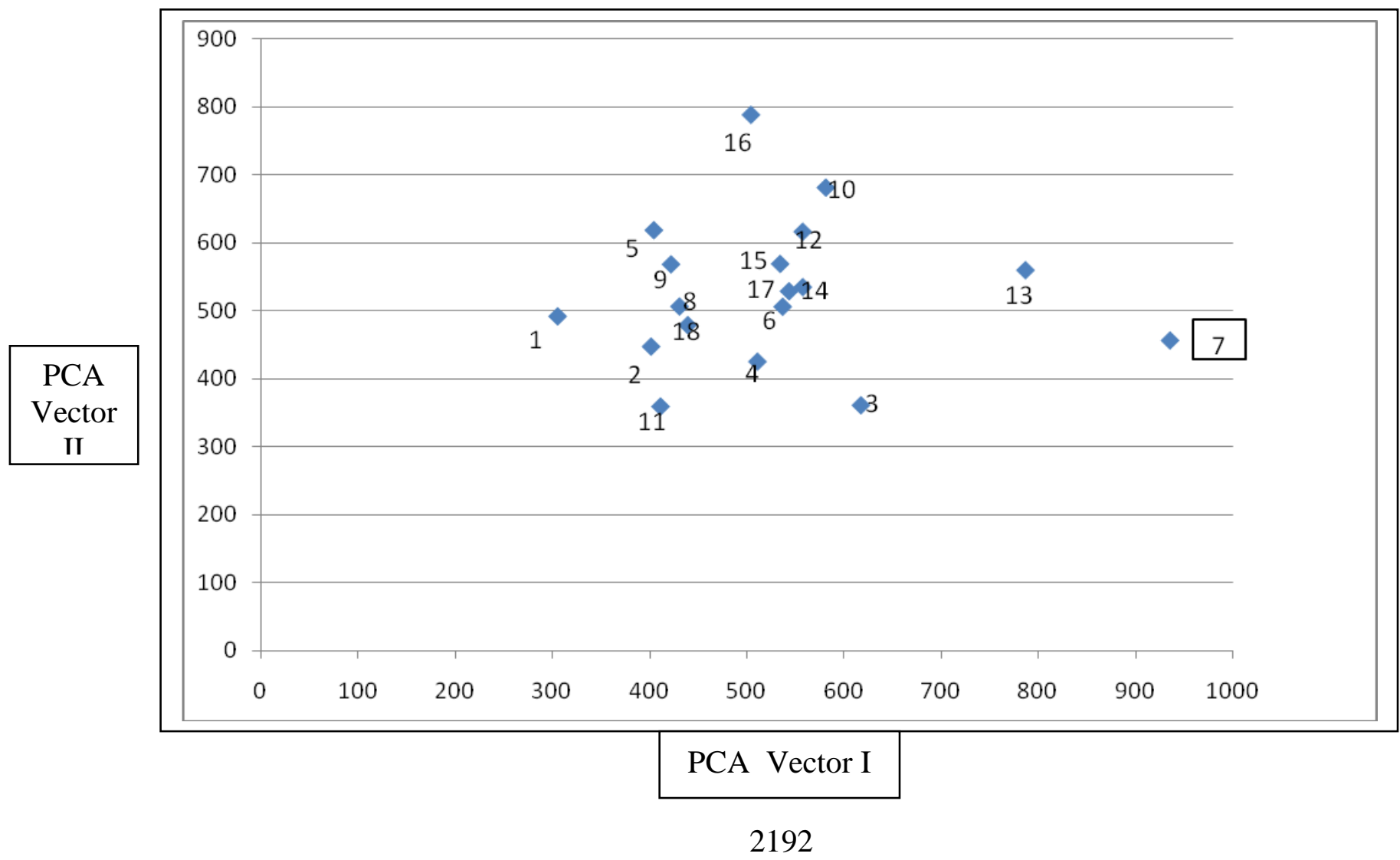


Cluster I had the highest mean values for branches/plant and fruits/plant (Table 4). Cluster II had the maximum mean values for node to $1^{\text {st }}$ female flower, fruit length, seeds per fruit and weight of seeds/ fruit. Cluster III had the highest mean values for number of female flowers/plant, sex ratio, average fruit weight, fruit girth, vine length and fruit yield/plant. Cluster III showed the lowest mean values for node to $1^{\text {st }}$ female flower and days to $1^{\text {st }}$ fruit setting. It indicated that genotypes of this cluster had desirable attributes towards earliness. Relative contribution of fruit yield per plant to genetic divergence of genotypes in ash gourd was the maximum, followed by vine length, fruit girth and seeds/ fruit (Table 5). Relative contribution of fruit yield per plant to genetic divergence of genotypes in ash gourd was the maximum which is in agreement with the findings of Gupta et al., (2016).

On the basis of the present findings, it may be inferred that crosses between parents selected from the divergent clusters I and III are expected to result in higher level of heterosis in the $F_{1}$ and possibly transgressive segregants in the subsequent generations as well. Similarly, earlier researchers (Kumar et al., 2006; Sureja et al., 2006; Dey et al., 2007 and Verma et al., 2007) had also shown that selection of parents from divergent clusters resulted in heterotic hybrids. However, when divergent parents are crossed, heterosis is not found to occur always. This is in conformity with the findings of other researchers (Dewan et al., 2013; Sahu et al., 2015) It is, therefore, essential to explore the possible limits to parental divergence for occurrence of heterosis.

The present study helped in understanding the diversity in the accessions studied and indicated the need for evaluating large number of accessions so as to identify even more promising and desired germplasm for crop improvement. Being a potential crop of the future, collection programmes from major ash gourd growing areas as well as non-traditional areas should be planned along with introduction from South East Asian and South Asian countries like China (Gangopadhyay et al., 2008).

Principal components analysis (PCA) performed on quantitative traits revealed that the first four most informative components accounted for $71.51 \%$ variance (Table 6). It also presented the descriptors with greater weightings in each of the four principal component axes. Characteristics of each Principal Component (PC) were determined on the basis of estimated factor loadings. Descriptors with greater weightings were fruit weight, fruit diameter, yield/plant, fruit length, weight of seeds/ fruit, branches/plant and vine length in PC1; seeds/fruit, weight of seeds/ fruit, days to $1^{\text {st }}$ fruit setting, female flowers /plant, fruit length and fruits/plant in PC2; vine length, branches/plant and weight of seeds/fruit in PC3; sex ratio, fruits/plant and yield/plant in PC4.

The scatter plot of PC scores of first two PC axes is presented in Figure 1. The Principal Components Analysis (PCA) in general confirmed the groupings obtained through cluster analysis with some deviations. A few distinct accessions could be marked. In some cases, the pairs of accessions originating from the same locations fall into tight groups within clusters whereas other accessions from the same location, are far apart in ordination.

The multivariate analysis might be effective in indicating high yielding accessions in different clusters which could be usefully intercrossed. The PCA ordination revealed that while the scatters of points for the clusters have a central focus, there are significant outliers to some groups. This presumably comes from the third PC. The outliers and central clusters provide the opportunity to identify representatives from the central as well as outliers for use in breeding. The genotype BAGS-1(cluster I) may be 
crossed with BAGS-7 (cluster II) or with the genotypes BAGS-10, Kashi Ujwal or Pusa Urmi (cluster III) for higher heterosis. The present findings are in agreement with those of Gangopadhyay et al., (2008). The high morphological diversity observed among the genotypes, emphasizes the need to expand the genetic base of the crop (Kalyanrao et al., 2016).

In conclusions, results revealed the existence of wide genetic divergence among the landraces collected from very small to small geographical areas in villages of Odisha state. It is a new contribution to knowledge since this finding was not reported by researchers earlier. Genetic divergence was not strictly in agreement with geographical divergence.

Cluster I had the highest mean values for branches/plant and number of fruits/plant. Cluster III had the highest mean values for number of female flowers/plant, sex ratio, average fruit weight, fruit girth, vine length and fruit yield/plant. Cluster III showed the lowest mean value for node to $1^{\text {st }}$ female flower and days to $1^{\text {st }}$ fruit setting. Relative contribution of fruit yield per plant to genetic divergence of genotypes in ash gourd was the maximum, followed by vine length, fruit girth and seeds/ fruit. Crosses between parents selected from the clusters I and III are expected to produce highly heterotic hybrids or transgressive segregants possibly combining earliness, higher number of fruits/plant, fruit weight and fruit yield/plant. The fact that cluster I contains all the landraces and no released varieties at all, also opens up newer possibilities of selecting promising genotypes which have genetic distinctness and almost no genetic similarity with the released varieties presently available in India This is a new contribution to knowledge.

The Principal Component Analysis, in general, confirmed the groupings obtained through cluster analysis (Tocher's) with some deviations. PCA revealed four informative components accounting for $71.51 \%$ variance. PC1 was related with fruit weight, fruit diameter, yield/plant, fruit length, weight of seeds/ fruit, branches/plant and vine length. The genotype BAGS-1(cluster I) may be crossed with BAGS-7(cluster II) or with the genotypes BAGS-10, Kashi Ujwal or Pusa Urmi(cluster III) for higher heterosis.

\section{Acknowledgements}

The authors acknowledge with thanks the facilities provided by the All India Coordinated Research Project on Vegetable Crops, Orissa University of Agriculture and Technology, Bhubaneswar, India and Indian Institute of Vegetable Research, Varanasi. Seeds of released varieties were provided by the Indian Agricultural Research Institute, New Delhi and Indian Institute of Vegetable Research, Varanasi.

\section{References}

Dewan, M.M.R., Mondal, S.I., Mukul, M.H.R. and Hossen, M.A.2014. Study on correlation and path analysis of the yield contributing characters of different ash gourd accessions. Eco-friendly Agril. J., $7: 01-05$.

Dey, S. S., Behera, T. K., Munshi, A.D. and Sirohi, P.S.2007. Studies on genetic divergence in bitter gourd (Momordica charantia L.). Indian J. Hort., 64 :5357.

Gangopadhyay, K.K., Kumar, Gunjeet, Meena, B.L. and Bisht, I.S. 2008.Genetic diversity studies in ash gourd [Benincasa hispida (Thunb.) Cogn.] from northern India. J. Plant Genet. Resour, 21: 206-212.

Gupta, Nivedita, Bhardwaj, M.L., Singh, S.P and Sood, Sonia. 2016. Genetic diversity for growth and yield traits in bitter gourd. International J. Veg. Sci., 22: 480-489.

Kumar, J., Singh, D. K. and Ram, H. H.2006. Genetic diversity in indigenous germplasm of pumpkin. Indian J. Hort., 63: 101-02. 
Kalyanrao, Kalyanrao, Tomar, B. S., Singh, Balraj and Aher, B. M. 2016. Morphological characterization of parental lines and cultivated genotypes of bottle gourd (Lagenaria siceraria). Indian J. Agric. Sci., 86(1): 65-70.

Lovely, B. and Devi, D. S. R.2004. Genetic divergence in ash gourd (Benincasa hispida Cogn.). Bioved., 15:57-60.

Mahalanobis, P. C. 1936. On the generalized distance in statistics. Proc. Nat. Inst. Sci., 12: 49-55.

Mandal, J., Sirohi, P. S. and Behera, T. K.2002. Inheritance of fruit characters in ash gourd (Benincasa hispida (Thunb.) Cogn.). Veg. Sci., 29: 113-15.

Matthew, P.J. 2003. Identification of Benincasa hispida (wax gourd) from the Kana archaeological site, Western Highlands Province, Papua Guinea. Archaeol. Ocea., 38: 186-191.

Pandey, A. K. 2008. Underutilized vegetable crops. Satish Serial Publishing House, Delhi.

Pandey, A. K., Bhardwaj, D. R., Dubey, Rakesh Kumar, Singh, Vikas and Pandey, S. 2015. Botany, diversity, utilization and improvement of ash gourd (Benincasa hispida Thunb. Ex Murray Cogn)—A review. Annals of Hort., 8: 1-15.

Panse, V.G. and Sukhatme P.V.1978. Statistical methods for agricultural workers. Indian Council of Agricultural Research, New Delhi.
Rao, C. R. 1952. Advance statistical methods in biometric research. John Wiley and Sons, Inc., New York.

Robinson, R.W., Decker-Walters, D.S. 1997. Cucurbits. CABI Publishing, Cambridge.

Rubatzky, V. E., Yamaguchi, M. 1997. World Vegetables. Chapman and Hall, New York.

Sahu, P. K., Sharma, D. and Nair, S. K.2015. Performance of ash gourd genotypes for earliness and yield under Chhattishgarh plains. Plant Arch., 15:1157-1160.

Singhal, Preeti, Singh, D. K., Damke, Sujata R. and Choudhary, Harshawardhan. 2010. Genetic diversity in indigenous germplasm of ash gourd. Indian $J$. Hort., 67 (Special Issue): 208-213.

Sureja, A. K., Sirohi, P. S., Behera T. K. and Mohapatra, T. 2006. Molecular diversity and its relationship with hybrid performance and heterosis in ash gourd [Benincasa hispida (Thunb.) Cogn.]. J. Hort. Sci. Biotech., 81:33-38.

Tindall, H.D.1986. Vegetables in the Tropics. Macmillan Education Ltd. Basingstake, Hampshire.

Verma, V. K., Behera, T. K., Munshi, A. D. Parida, S. K. and Mohapatra, T. 2007. Genetic diversity of ash gourd [Benincasa hispida (Thunb.) Cogn.] inbred lines based on RAPD and ISSR markers and their hybrid performance. Sci. Hortic. 113: 231-237.

\section{How to cite this article:}

Kalyani Pradhan, Alok Nandi, Swarnalata Das, Subrata Sarkar, Gouri Shankar Sahu and Anjana Patnaik 2018. Genetic Diversity Analysis of Ash Gourd [Benincasa hispida (Thunb.) Cogn.] Germplasm by Principal Components. Int.J.Curr.Microbiol.App.Sci. 7(03): 2187-2195. doi: https://doi.org/10.20546/ijcmas.2018.703.258 